老人ホーム在住健常老人に打ける脳血流量, 知的機能の経年変化

\author{
小林 祥泰山口 修平 木谷 光博 \\ 岡田 和悟 有元佐多雄
}

要約：我々は脳の老化における個人差の一つの要因として, 社会的環境因子が重要であるこ とを報告してきた。今回は前回脳血流を測定した健常老人の5ち, 脳の老化が地域在住老人に 比し進行していた老人ホーム在住老人 20 名について脳血流と知的機能の 2 年 6 カ月の経年変化 を検討した。その結果, 全脳平均脳血流は有意な変化を示さず, 脳血流に抢ける加齢性変化は 少なくともこの間には認められなかった。動作性知能に関しても明らかな低下は認められな かったが脳血流の低下した群では低下傾向がみられた。一方, 言語性知能は平均 $7.5 \%$ と軽度で はあるが有意な低下を示したが，脳血流の変化率や年齢との間に相関はなかった．脳血流に関 連した parameter には変化は認められず, 一般身体所見にも変化はみられなかった。老人ホー ムにおいても, 健常で日常生活の活動性を維持している限り，2 年 6 カ月程度の短期間では脳 血流の加齢性減少は少ないことが示唆された。

Key words : 健常老人, 脳血流, 老人ホーム, 経年変化, 知的機能

(脳卒中 $8: 237-242,1986$ )

脳の神経細胞は加齢と共に減少し, それに伴って脳 血流も減少することが知られている1) 3). しかし，この 减少には個人差が大きく関与して括り，正常な社会生 活を営んでいる人では, PETによる検討で脳グルコー ス代謝の低下が見られないとする報告もある4)5 . 我々 も脳の老化に対する社会的環境因子の重要性について 脳血流の面から検討し報告してきだ). 今回は前回検 討した健常老人のうち老人ホーム在住健常老人につい て脳血流量を経時的に測定し同一個人に打ける経年変 化すなわち縦断的検討を行ったので報告する。

\section{対象}

2 年半前に脳血流測定を行った老人ホーム在住の健 常老人 33 名のうち, 経年变化を追跡し穴た男性 8 名, 女性12名, 計20名 (平均76歳) を対象とした。前回測 定者のうち測定できなかった人の内訳は，この間に死 亡した者 4 名(脳卒中死亡はなし), 帰宅者 5 名, 病気 あるいは都合による不参加 4 名であった. 全員を前回 と同様筆者が診察し, 神経学的異常のないことを確認 した。この間に大病をした例はこの対象のなかには含 まれて招らず, 一般身体所見でも特に変化は認められ

島根医科大学第 3 内科
なかった。診察した印象では 2 年前に比し，それほど 老化が進んでいないように思われた。老人ホームの看 護婦さんの話でも, 明らかな知能低下を示した例はな かったという。この老人ホームでは 3 食バイキング方 式をとっており, また, 趣味のクラブ活動も盛んで, 色々な脳の老化防止策がとられているのが特徵であ る7).

\section{方法}

\section{1）局所脳血流測定法}

${ }^{133} \mathrm{Xe}$ 吸入法8)により, NOVO 社製16ch-Cerebrograph を用いて測定した。吸入した ${ }^{133} \mathrm{Xe}$ ガス濃度は 約 $3 \mathrm{mCi} / \mathrm{L}$, 全測定時間は約 15 分である. 左右各 8 個の 検出器を気道からの artifact を避けるため副鼻腔をさ けて脳矢状面に垂直に配置した。局所脳血流量 ( $\mathrm{rCBF}$ ) としてフーリエ解析法による F1值 (灰白質血 流を示す)を用いた。 $\mathrm{rCBF}$ 測定時には呼気炭酸ガス濃 度をカプノグラフ（Datex 社製 Normocap）にて連続 記録し，これを呼気終末炭酸ガス分圧 $\left(\mathrm{PeCO}_{2}\right)$ に換 算して用いた。 また，同時に血圧，へモグロビン $(\mathrm{Hb})$, ヘマトクリット $(\mathrm{Ht})$, 血清脂質, $\mathrm{Wu}$ ら $^{9)}$ の方法によ る非凝集血小板率（流血中で凝集していない血小板の 比率) を測定. 心電図検查も行い, 前回のデータと比 
較検討した。 さらに, 今回は頭頂部と後頭部で左右各 2 チャンネルの脳波記録も行った.

$\mathrm{rCBF}$ の長期再現性については, 症状に変化のな かった12例の TIA どの症例ですでに検討してあ $\eta^{10)}, 7$ 日から 28 日, 平均 $20.3 \pm 11.9$ 日の間隔を㧊いて の測定で変化率がー2.3土7.5\%, CV\%が7.9\%とほぼ 良好な結果を得ている。この結果は，長期にわたる $\mathrm{rCBF}$ の観察にも ${ }^{133} \mathrm{Xe}$ 吸入法が十分耐兄らることを 示している.

\section{2）知的精神機能の評価}

前回と同様, 言語性知能の評価には長谷川式簡易知 能スケールを用い, 動作性知能の評価は Kohs'block design testにより行ない, 経年変化を検討した.

得られた結果の統計学的検討には paired t-test, Student t-testを用いた。

測定間隔は約 2 年 6 力月である.

\section{結 果}

1) 脳血流に関連したパラメーターの変化について

平均血圧 (MABP) は 1 回目が平均103.8 14.8 $\mathrm{mmHg}$ (Mean $\pm \mathrm{SD}$ ), 2 回目が99.9 $\pm 11.9 \mathrm{mmHg}$ と 有意の変化を認めなかった. $\mathrm{Ht}$ も 1 回目 $37.9 \pm 4.8 \%$, 2 回目 $36.6 \pm 4.5 \%$ と殆ど変化を示さなかった。 また, $\mathrm{PeCO}_{2}$ についても, 1 回目 $37.9 \pm 2.1$ torr, 2 回目 $38.0 \pm 2.9$ torr と変化は見られなかった。 血清脂質に ついても同様で総コレステロールが各々 $182.6 \pm 47.4$ $\mathrm{mg} / \mathrm{d} l, 191.3 \pm 48.1 \mathrm{mg} / \mathrm{d} l, \mathrm{HDL}$ コレステロールが $49.0 \pm 12.0 \mathrm{mg} / \mathrm{d} l, 52.1 \pm 11.6 \mathrm{mg} / \mathrm{d} l$ と変化を認めな かった。 また個々の例でこれらの值が極端に変化した 例はなかった。非凝集血小板率も各々 $84.7 \pm 77.7 \%$, $90.8 \pm 5.6 \%$ と有意の变化を認めなかったが,一部の例 では明らかな低下すなわち血小板機能立進がみとめら れ, そのうち 1 例では脳血流の減少との関連も認めら れた。

脳波は全例 $\alpha$ から $\beta$ 領域にあり異常脳波は認めら れなかった。

\section{2) $\mathbf{r C B F}$ の経年変化}

平均 $\mathrm{rCBF}$ は 1 回目右半球 $60.1 \pm 13.0 \mathrm{~m} l / 100 \mathrm{~g} /$ $\min$, 左半球 $61.6 \pm 11.4 \mathrm{ml} / 100 \mathrm{~g} / \mathrm{min}$., 2 回目各々 $61.2 \pm 13.9 \mathrm{ml} / 100 \mathrm{~g} / \mathrm{min}$., $59.7 \pm 14.0 \mathrm{ml} / 100 \mathrm{~g} / \mathrm{min}$. であり, 図 1 のごとく，個々の例については若干のば らつきはあるものの, 全体としてはその変化率は右半 球で $1.0 \pm 11.2 \%$, 左半球で $-1.9 \pm 10.1 \%$ と有意の変 化を示さなかった。全脳平均の変化率は一 $-0.43 \pm$

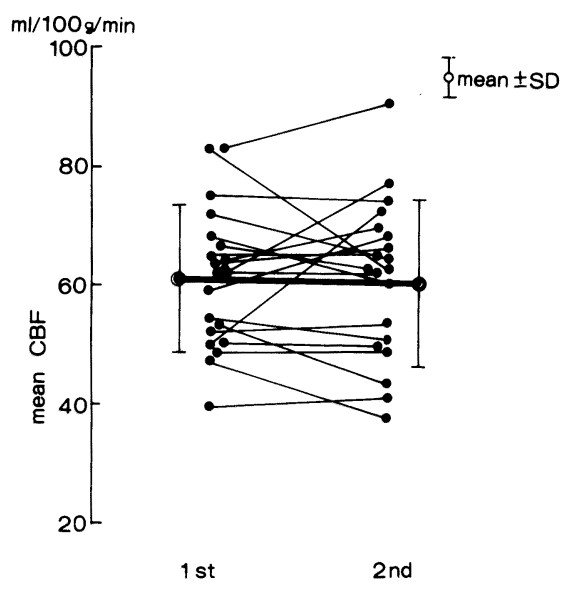

図 1 全脳平均血流量の経年変化

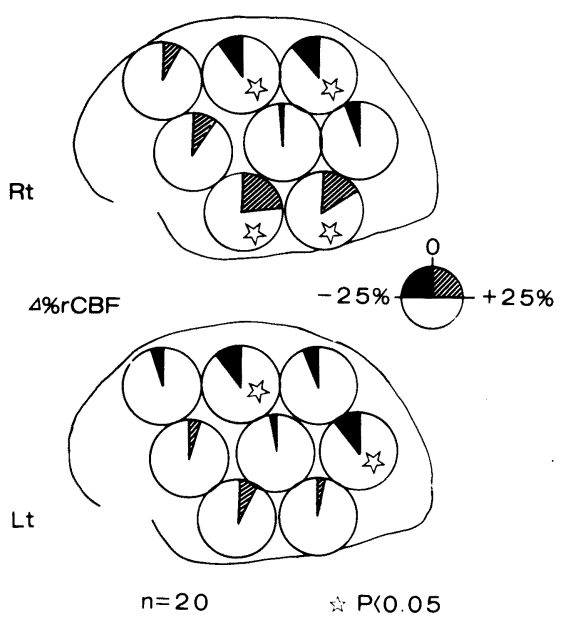

図 2 局所別にみた脳血流量の経年変化

10.3\%で, CV\%は17\%であった. 1 回目の年齢, $\mathrm{rCBF}$, $\mathrm{MABP}, \mathrm{PeCO}_{2}, \mathrm{Ht}$, 非血小板凝集率などと $\mathrm{rCBF}$ の 変化率との間には有意の相関はみられなかった。 また， $\mathrm{MABP}, \mathrm{Ht}, \mathrm{PeCO}_{2}$ の変化率と $\mathrm{rCBF}$ の変化率との間 にも相関が見られなかった。 1 回目と 2 回目の $\mathrm{rCBF}$ は全脳平均で（ $\mathrm{r}=0.7 （ \mathrm{p}<0.005 ）$ とほほ良好な相関 を示した。各チャンネル別にみても右側頭部の 1 箇所 （Ch7）を除き良好な相関がみとめられた。

局所脳血流の变化率については図 2 に示したごとく で，有意の経年的减少が両側頭頂部で見られたが，右 半球では前頭側頭部にむしろ増加した部位もみられ，

一定の傾向は認められなかった。

脳血管抵抗 $(\mathrm{CVR})$ 。 1 回目1.76, 2 回目 1.73 と変 化はみられなかった。 

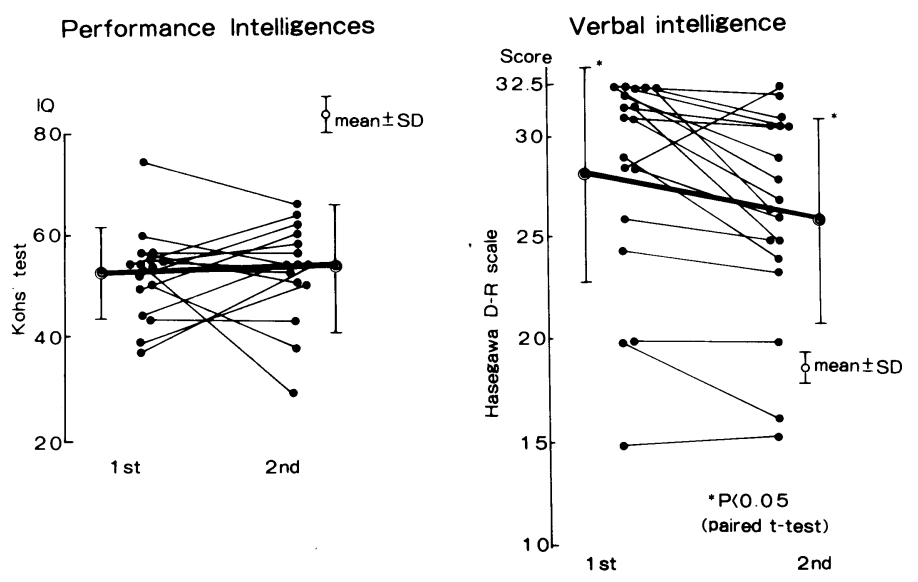

図 3

A) 動作性知能 (Kohs's test IQ) の経年变化

B) 言語性知能 (長谷川式知能スコア) の経年変化

\section{3）知的精神機能の経年変化}

言語性知能（長谷川スコア）の変化は図 $3 \mathrm{~B}$ に示し たごとくで, 殆どの例で軽度から中等度の低下を示し ている. 平均值では 1 回目の $28.2 \pm 5.4$ 点に比し, 2 回 目は $25.9 \pm 5.0$ 点と $-7.5 \pm 9 \%$ 軽度ではあるが，有 意の低下が認められた $(\mathrm{p}<0.05)$.

動作性知能 (Kohs'IQ) の変化は図 $3 \mathrm{~A}$ に示したご とくである. 学習効果によるものか, むしろ IQ が上昇 した例も見られており,全体の平均では, 1 回目 $52.9 \pm$ 8.9, 2 回目 $54.5 \pm 12.3$, 変化率 $1.1 \pm 4.2 \%$ と有意の変 化は見られなかった。

しかし, 全脳平均 rCBF が少しでも減少した群（9 例）と減少しなかった群（11例）に分けてこれらの知 能テストの結果を比較してみると, 図 4 のごとく動作 性知能の変化率に打いて両群間に有意の差が認められ た. 即ち, 脳血流の減少と動作性知能の低下には若干 の関連がある可能性が示された。一方, 言語性知能の 変化率は両群間で差を認めなかった。しかし, 全脳平 均 $\mathrm{rCBF}$ の変化率と動作性知能あるいは言語性知能 の变化率との間には有意の相関関係は認められなかっ た。また， 1 回目， 2 回目共に $\mathrm{rCBF}$ と各知能との間 に相関は見られず, 1 回目の $\mathrm{CBF}$ と各知能の变化率 との間にも相関はみられなかった。言語性知能の変化 率と年齢との関係, 即ち, 高齢であるほどその低下が 強いといら傾向もみられなかった。言語性知能の 1 回 目と 2 回目の相関係数は $\mathrm{r}=0.89(\mathrm{p}<0.001)$ と良好な 相関を示したが，動作性知能に関しては有意の相関が みられなかった。

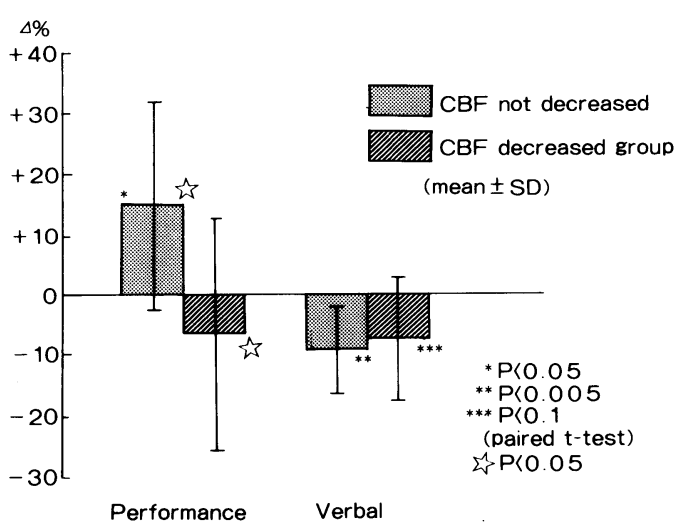

図 4 脳血流減少群と非減少群における動作性知能, 言語性知能の経年変化の比較

\section{考案}

知的能力に対する加齢の影響を正常な双子の老人に ついて 8 年間にわたり縦断的に検討した Jarvik の報 告 ${ }^{11)}$ では60歳から70歳までの間に衰退した知能は $7 つ$

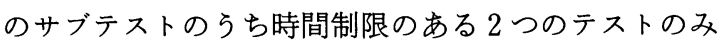
であったとし，ごくわずかの例を除き知的能力が直接 的に老化しないことを示している.脳血流に関しては, かなり直線的に減少するという報告3)もあるか， Ketty ${ }^{11}$ は30歳以降は70歳位まで脳血流の減少は極め て緩徐であるとしている. Shaw ら ${ }^{12)}$ の横断的検討で は, 70歳を越すとその減少率が明らかに増加するとし ている。一方, Fazekas ${ }^{13)}$ は, 平均93歳の超高齢老人に ついて脳血流を測定し, 104歳でも正常範囲内にある例 
があることを示し，脳の老化は個人差が大きいことを 述べている，正常人に扔いては，脳血流量と脳代謝は coupling しているので, これらの研究に打ける脳血流 の変化は脳動脈硬化により動脈内腔が狭窄したためと いらよりは脳代謝の変化を主として反映しているもの と考学られる.脳の老化に扔ける個人差の要因として, 我々は社会的環境因子に注目し, 老人ホーム在住健常 老人と地域在住の社会的活動性の比較的高い老人に㧤 いて脳血流と知的機能を比較したが，前者において有 意の低下を認めた。このことは，過去および現在の人 生に扮ける満足度(幸福度), 社会的刺激の多寡が脳の 老化に密接に関与していることを示すものである6). 今回は前回の結果から考㝋て, 脳の老化の進行により 速いと予測された老人ホーム在住老人について, 経年 変化を検討したが，その結果はむしろ予測に反するも のであった。すなわち，脳血流量および動作性知能に 関しては 2 年 6 カ月の間に有意の変化は見られず，言 語性知能のみ $-7.5 \%$ と軽度の低下を示した. 70 歳を過 ぎると，老化の進行速度が早まっている ${ }^{12)}$ と考兄られ るにもかかわらず，このように平均76歳であっても， しかも, 老人ホーム在住であっても, 脳の老化の進行 が緩徐であったことは注目すべき結果であると考兄ら れる. 脳血流の経年変化についてはShaw ら ${ }^{12)}$ が脳卒 中の危険因子を有するが脳疾患の既往のないVolunteer とこれらの危険因子を有さない健康人拉よび脳 血管障害患者について 4 年間にわたる追跡調查を行 い, 平均62歳の健康人であっても初回測定時平均約 72 $\mathrm{m} l / 100 \mathrm{~g} / \mathrm{min}$ から 4 年後には $69 \mathrm{~m} l / 100 \mathrm{~g} / \mathrm{min}$ と軽度 ではあるが有意の低下を示したとしている。この低下 は危険因子を有する群では，有さない群に比し有意に 大であったという。また脳血管障害群ではその臨床的 重症度と脳血流の低下の度合が相関していたという。 この結果は彼等の多数例による横断的検討の結果と一 致するものであった。

Barclay ら ${ }^{13)}$ は正常者と痴呆例において ${ }^{133} \mathrm{Xe}$ 吸入 法で同様に 6 カ月から 3 年の経年変化を検討し, 痴呆 群では脳血流の低下速度がー0.6/month と正常者 のー0.013/monthに比し明らかに大きかったとして いる。しかし，彼等の経年変化を検討した正常例はわ ずか 4 例にすぎず統計学的に問題が残る。一方, 我々 が痴呆のない軽症基底核小梗塞症例14例で約 2 年の経

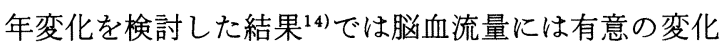
は認められなかったが，我々がすでに報告した CT の 脳萎縮の二次元的定量的評価法 ${ }^{15)}$ でみると, 大脳の有
意な萎縮が認められた。 CT 上の大脳萎縮の経年変化 についてはGado ら ${ }^{16)}$ が正常老人とSDATで volumetric 法で検討し, SDAT では正常老人に比し明 らかに萎縮の進行が速いが，正常老人でも脳室と脳溝 の頭蓋内腔に対する容積比が, 1 年間の観察期間に $11.3 \%$ から $12.39 \%$ と軽度ながら有意に増大し, 脳萎縮 が認められたとしている，Rapport ら4はPETによ り, 各年代の正常者の脳ブドウ糖代謝を測定し，加齢 による低下を認めなかったとしている。これらの結果 は脳神経細胞の脱落はある程度 constant に進行して いても，脳機能は代償作用により保たれ，脳機能低下 が遅れて生じる可能性を示している. 今回, 対象とし た老人ホーム在住老人は社会的活動性の比較的高い地 域老人に比し脳血流, 知的機能の低下がかなり先行し ており，この 2 年 6 力月でさらにその差が拡がるので はないかと推測していたが, 結果的には軽度の言語性 知能の低下を除き，よく保たれていた。これはこの老 人ホームのバイキング方式を初めとするュニークな老 化予防策が有効であることを示すものかもしれない。 柄沢 ${ }^{18)}$ は平均 70 歳の知的優秀女性146例を対象に, 知 能と脳波について 3 年間の糈断的研究を行っている. その結果では, 3 年間で脳波に有意の変化はみられず, Benton 視覚記銘検査の成績も不変であったが, Kohs' test による動作性知能は平均 87 から 83 と有意に低下し たとしている。亦た，脳波の悪化度と動作性知能の低 下度が相関していたとしている．これは，我々の結果 で脳血流量が減少した群で動作性知能が低下していた ことと関連して興味深い。我々の対象群は柄沢ら ${ }^{18)}$ それに比し，高齢であり，かつ一回目の Kohs' test の 成績もかなり悪く質的に異なっている。しかし，これ らの相違は加㱓に伴う生理的な知能低下は, 動作性知 能から生じるが，ある年齢を越すと言語性知能の廃用 性衰退 ${ }^{19)}$ が目立ってくる可能性を示唆しているとも考 えられる，今後さらに，社会的活動性の高い地域在住 老人に打ける経年变化と比較し，この点に関しても検 討する予定である。

本研究にあたり, ご協力を戴いた島根難病研究所の村尾 光好技師をはじめとする職員の皆様に深謝致する。また，実 際の研究にご協力戴いた島根医大第 3 内科の勝部知子医 師，藤原茂芳助手，下手公一医師，村田昭博医師，山下一也 医師, 小出博已医師, 扣よびご指導戴いた恒松徳五郎教授に 深謝する。

本研究費の一部は千代田生命健康事業団昭和59年度研究 助成金によった。また, 本研究の要旨は第10回日本脳卒中学 
会で報告した。

$$
\text { 文献 }
$$

1) Kety SS: Human cerebral blood flow and oxygen consumption as related to aging. J Chronic Dis 3 : 478-486, 1956

2) Naritiomi H, Meyer JS, Sakai F, et al: Effects of advancing age on regional cerebral blood flow. Studies in normal subjects and subjects with risk factors for artherothrombotic stroke. Arch Neurol 36 : 410-416, 1979

3) Melamed E, Lavy S, Bentin S, et al: Reduction in cerebral blood flow during normal aging in man. Stroke 11: 31-34, 1980

4) Rapoport SI, Duara R, Kessler RM, et al: Brain aging in 40 healthy men: rCMRglc and correlated functional activity in various brain region in the resting stage. J Cereb Blood Flow Methol 3(Suppl 1) : s484-s485, 1983

5) de Leon MJ, Ferris $\mathrm{SH}$, George $\mathrm{AE}$, et al: Positron emission tomographic studies of aging and Alzheimer disease. AJNR $4: 568-571,1983$

6) 小林祥泰, 山口修平, 勝部知子品か: 正常高齢者の 脳循環. 大脳機能に及ぼす社会的環境因子の影響. 脳卒中 $5: 338-346,1983$

7）綿織義宣：老人ホームからの発想. 京都, ミネルバ 書房, 1982

8) Obrist WD, Thompson HK, Wang HS, et al : Regional cerebral blood flow estimated ${ }^{133} \mathrm{Xe}$ inhalation. Stroke 6: 245-256, 1975

9) Wu KK, Hoak JC: A new method for the quantitative detection of platelet aggregates in patients with arterial insufficiency. Lancet 2 : 924-926, 1974
10) Kobayashi $S$, Yamaguchi $S$, Katsube $T$, et al: Long-term effect of cilostazol on cerebral blood flow in chronic cerebral infarction. Arznei. Fosch 35(11) : 7a, 1193-1197, 1985

11) Jervik LF, Kallman FJ, Falek A : A intellectual changes in aged twins. J Geront 17: 289 $-294,1962$

12) Shaw TG, mortel KF, Meyer JS, et al: Cerebral blood flow changes in benign aging and cerebrovascular disease. Neurology (Cleveland) $34: 855-862,1984$

13) Fazekas JF, Kleh J, Witkin L: Cerebral hemodynamics and metabolism in subjects over 90 years old age. J Am Geriat Soc $1: 836-839$, 1953

14) Barclay L, Zemcov A, Blass JP, et al: Rates of decrease of cerebral blood flow in progressive dementias. Neurology (Cleveland) $34: 1555$ $-1560,1984$

15）木谷光博, 小林祥泰, 山口修平湾： CT scan に よる大脳の加龄性萎縮の検討. Digitizerによる断 面積比を用いて。 CT 研究 $6: 659-661 ， 1984$

16）木谷光博, 小林祥泰, 山口修平ほか: 穿通枝領域脳 梗塞に抢ける脳血流量と CT 所見の経年変化. 第 10回日本脳卒中学会抄録集, p164, 1985

17) Gado $M$, Hughes $C P$, Danziger $W$, et al: Aging. dementia and brain atrophy: A longitudinal computed tomographic study. AJNR 4: 699-702, 1983

18）柄沢昭秀, 川島寛司：優秀女性老人脳波の 3 年後 の変化。臨床脑波 $22: 1-8,1980$

19）柄沢昭秀, 川島寛司, 長谷川和夫：臨床評価に上る 知的老化の研究. 精神医学 $17: 373-383,1975$ 


\title{
Abstract \\ A longitudinal study of cerebral blood flow and intelligences in normal elderly people living in retirement house
}

\author{
Shotai Kobayashi, M.D., Shuhei Yamaguchi, M.D., Mitsuhiro Kitani, M.D., \\ Kazunori Okada, M.D. and Satao Arimoto, M.D. \\ 3rd Department of Internal Medicine, Shimane Medical University
}

It is well known that the number of the neuron in the brain gradually reduced with advancing age, but speed of decline of brain functions differs among individuals. We have reported that social environmental factors had significant influences to cerebral blood flow (CBF) and mental function.

In this paper, we report 2.5 years longitudinal study concerning with $\mathrm{CBF}$ and intelligences in twenty normal elderly people, mean age of 76 years old at the first measurement, living in retirement house.

1) Mean CBF measured by Xe133 inhalation method did not alter significantly during the observation period.

2) Performance intelligence evaluated by Kohs' block design test had reduced at the point of begining but no more reduction was observed during the period.

3) Verbal intelligence evaluated by Hasegawa's intelligence scale for aged which was within normal range at the begining, slightly $(-7.5 \%)$ but significantly $(p<0.05)$ reduced during the period.

4) Performance intelligence tended to reduce in subjects who showed reduction of $\mathrm{CBF}$. There were no significant correlation between both intelligences and CBF.

CBF could be maintained even in elderly people living in retirement house which has less social stimuli during relatively short observation period in so far as they maintain active daily life. The speed of reduction of performance intelligence may be getting slow after certain age and verbal intelligence gradually decreases perhaps by disuse of the mental function.

(Jpn. J. Stroke 8: 237-242, 1986) 